\title{
Entrepreneurs and the Co-Creation of Ecotourism in Costa Rica
}

\section{Citation}

Jones, Geoffrey, and Andrew Spadafora. "Entrepreneurs and the Co-Creation of Ecotourism in Costa Rica." Harvard Business School Working Paper, No. 16-136, June 2016.

\section{Permanent link}

http://nrs.harvard.edu/urn-3:HUL.InstRepos:31680683

\section{Terms of Use}

This article was downloaded from Harvard University's DASH repository, and is made available under the terms and conditions applicable to Open Access Policy Articles, as set forth at http:// nrs.harvard.edu/urn-3:HUL.InstRepos:dash.current.terms-of-use\#OAP

\section{Share Your Story}

The Harvard community has made this article openly available.

Please share how this access benefits you. Submit a story.

\section{Accessibility}




\section{Entrepreneurs and the Co-Creation of Ecotourism in Costa Rica}

Geoffrey Jones

Andrew Spadafora

Working Paper 16-136 


\title{
Entrepreneurs and the Co-Creation of Ecotourism in Costa Rica
}

\author{
Geoffrey Jones
}

Harvard Business School

Andrew Spadafora

Harvard Business School

Working Paper 16-136 not be reproduced without permission of the copyright holder. Copies of working papers are available from the author. 


\title{
Entrepreneurs and the Co-Creation of Ecotourism in Costa Rica
}

\author{
Geoffrey Jones and Andrew Spadafora
}

\begin{abstract}
Between the 1970s and the 2000s Costa Rica became established as the world's leading ecotourism destination. This working paper suggests that although Costa Rica benefited from biodiversity and a pleasant climate, the country's preeminence in ecotourism requires more than a natural resource endowment explanation. The paper argues that the ecotourism industry was a co-creation of the public, private, and tertiary sectors. While the role of the government and conservation NGOs is acknowledged in the existing literature, this study draws attention to the critical role of small entrepreneurs. Making extensive use of oral history, the working paper demonstrates the role of tour companies in drawing affluent Western ecotourists to the country, and of the creators of ecolodges and other forms of accommodation in providing them with somewhere to stay. These entrepreneurs, many of them expatriate Americans, helped ensure that formally protected areas remained sustainable parks and reserves, by providing revenues, education in conservation to tourists, and community development and jobs. Clustering created positive externalities for new entrepreneurs to enter the industry, who could also learn from knowledge spillovers. There were downsides to the new industry, however. The creation of the national image of a natural paradise enabled many businesses which were not environmentally sustainable to free-ride on the green image. Even values-driven ecotourism entrepreneurs faced questions about their impact as they expanded the scale of their operations. While scaling was a sign of success and delivered many benefits to Costa Rica, there were distinct drawbacks from a sustainability perspective.
\end{abstract}




\section{Entrepreneurs and the Co-Creation of Ecotourism in Costa Rica \\ Geoffrey Jones and Andrew Spadafora}

\section{Creating a Natural Paradise}

This working paper examines how the Central American nation of Costa Rica became a global center for ecotourism during the late decades of the twentieth century. This was an era when the country flourished as an overall tourist destination. Total tourist arrivals to the country increased from 155,000 in 1970 to 435,000 in 1990 , and reached 1.1 million in 2000 , with revenues generated by tourism growing from US\$21 million to $\$ 1.15$ billion over that period. ${ }^{1}$ The distinctive feature of this tourism boom, however, was that much of it appeared driven by ecological interests. There are porous boundaries between conventional tourism and ecotourism, which emerged as a defined concept quite recently. It was only in the 1990s that the non-profit International Ecotourism Society (TIES) articulated what became the mostly widely accepted definition of ecotourism as "responsible travel to natural areas that conserves the environment and improves the well-being of local people.” ${ }^{2}$ On the broad basis of that definition, a takeoff of ecotourism in Costa Rica was underway by the late 1980s, with visits to protected forest areas increasing from 287,000 in 1987 to 866,000 in $1999 .{ }^{3}$ By the late 1990 s, a survey suggested that the average foreign tourist spent approximately two-thirds of his or her time in Costa Rica in protected areas or traveling to them. ${ }^{4}$

International surveys came to place Costa Rica regularly at or near the top of ecotourism destinations. ${ }^{5}$ The standard text on ecotourism published in 2008 noted that "the country was perceived internationally as the world's prime ecotourist destination,” ahead of such forerunners as Kenya, Nepal, and the Galapagos Islands. ${ }^{6}$ The website IndependentTraveller.com notes that 
"Costa Rica is practically synonymous with the term 'ecotourism,' and for good reason." " "Costa Rica's renowned back-to-nature ethos," the ShermansTravel website declares, "has helped make the country synonymous with the concept of ecotourism.” ${ }^{8}$

The business history of tourism remains, as a pioneering study noted nearly a decade ago, only partially explored empirically, despite the size of the global industry and its economic, social, and environmental impact. It has long been evident that first-order endowments of natural resources or cultural heritage alone cannot explain the emergence of particular locations or countries as tourist centers. Rather, as Philip Scranton observed in the preface to that study, the emergent literature has identified the role that entrepreneurs and firms played in the commodification of "places." ${ }^{9}$ Laurent Tissot has shown the importance of hoteliers and railroad companies, for example, in the growth of the Swiss tourist industry in the nineteenth century, as the cold and barren mountains of the country were rebranded as healthy meccas for winter recreation. ${ }^{10}$ Similarly, railroad companies were important influences on the development of national parks and tourism in the American West. ${ }^{11}$ Other studies have traced the way in which airlines and hotel chains cooperated with governments to expand American tourist travel to Europe and Latin America after World War II. The emergence of the postwar travel trade not only reflected consumer demand to visit cultural and natural attractions but also responded to the changing ideas and interests of tourists and policymakers, such as the ideological currents of the Cold War and notions of comfort and familiarity. ${ }^{12}$

Research on the growth of tourism enterprises in Latin America has focused heavily on the introduction of air traffic routes from the United States by Pan American World Airways (Pan Am) and Braniff International Airways, and by large airline-owned or allied hotel chains like Intercontinental Hotel Corporation. ${ }^{13}$ In the categories of beach and tropical tourism, 
business historians have also prioritized investigation of large-scale resorts like Club Med and the often-troubling effects of post-1960 mass tourism on fragile environments like Maui. ${ }^{14}$ Although small-scale seaside destinations and enterprises have received increasing attention, and the cluster or "industrial district" model has been applied to the chiefly locally-owned tourism industry of the Balearic Islands, ${ }^{15}$ emphasis has remained on large multinational firms, European settings, and cultural, urban, and beach tourism.

The Costa Rican ecotourism case, by contrast, involves nature tourism conducted by small businesses, which remain understudied despite their importance within the industry more broadly. The fragmented ecotourism literature, too, has long neglected small, for-profit firms and entrepreneurs in favor of such topics as ecotourist characteristics and market segments, tourist impact on protected lands and wildlife, non-profit community-based ecotourism programs, and theoretical definitions of the field. Insofar as small firms have received attention, it has largely been to explain their high rate of failure, which may partly account for the lack of interest in longitudinal studies of more successful enterprises. ${ }^{16}$ The history of Costa Rican ecotourism not only fills these lacunae in one important national case. It also offers compelling evidence on the emergence of new tourism categories, the role of business in commodifying existing natural endowments, and the impact of changing ideas-in this case, conservation, biodiversity, and environmentalism—on both entrepreneurs and tourists. Ecotourism was only formally defined as a category in the late twentieth century, although it can be traced back to earlier decades of nature- and wildlife-based tourism in East Africa, Antarctica and the Galapagos Islands, as well as international birdwatching tours. ${ }^{17}$

The existing literature on the emergence of Costa Rican ecotourism has focused on the role of the state, especially the creation of the national park system. ${ }^{18}$ While acknowledging the 
role of public policy, this working paper argues that the growth of the ecotourism industry is better seen as a case of co-creation, involving small entrepreneurial start-ups operating private reserves, tours, and accommodations, as well as environmental and scientific NGOs. It draws on new primary sources, especially two sets of oral histories conducted in different time periods. These oral histories, although not to be taken simplistically at face value, nevertheless provide rich and nuanced information which cannot be found elsewhere, as few entrepreneurial start-ups, especially one located in jungles, keep extensive written records.

The following sections examine Costa Rica’s natural endowment and institutional foundations for tourism; the role of scientists, NGOs, and the national parks; the role of entrepreneurs and firms in the creation of the industry; and the overall impact of ecotourism on the country. A final section concludes.

\section{Natural Endowment and Institutional Foundations}

Costa Rica’s natural endowment was a mixed blessing for the emergence of an ecotourism industry. The country allegedly contains four to five percent of the world's biodiversity in 0.035 percent of its territory; about the size of West Virginia in land area, it has more bird species than all of the United States. ${ }^{19}$ It boasts twenty separate "life zones," some 850 species of birds, 1260 of trees, 237 of mammals, and 361 of reptiles. ${ }^{20}$ However, Costa Rica’s bounty also invited intensive logging, ranching, monoculture plantations of agricultural commodities, and eventually overdevelopment of some of its sunny beaches, all of which wreaked havoc on its forests and shorelines after the 1950s. Between 1940 and 1980, Costa Rica lost 2.5 million hectares of forest, with annual average deforestation rates reaching their height in the 1970 s at approximately 60,000 hectares per year. ${ }^{21}$ The country's primary forest cover had fallen from 90 percent in 1950 to just over 25 percent by $1990 .^{22}$ 
Costa Rica developed a growing domestic beach tourism market between 1950 and 1980, and began to improve its transportation infrastructure to service it. The completion of rail lines and expansion of the Pan-American Highway after 1946 eased access from the central population centers to the Pacific beaches of Guanacaste, which later became the most heavily overdeveloped tourism center. ${ }^{23}$ The country constructed more roads, raising its total to 30,000 kilometers by $1983 .{ }^{24}$ In 1957 , the government opened a modern international airport near San José. ${ }^{25}$ Work began on a second airport to serve the Guanacaste tourist region in the mid-1970s, but it was not opened to international air traffic until $1996 .{ }^{26}$ The national airline, LACSA, was established in 1945 by Pan American, the Costa Rican government and private investors, and operated routes to Miami and Latin American capitals. During the 1980s, LACSA became the largest Central American carrier. ${ }^{27}$

The government created a National Tourism Council in 1931, and replaced it in 1955 with the Costa Rican Tourism Institute (ICT), both of which mainly promoted domestic travel. ${ }^{28}$ The ICT was explicitly permitted to declare and protect national parks, but it never moved beyond preliminary studies. ${ }^{29}$ What international tourism there was—approximately 6,000-7,000 tourists annually in 1953-1954 ${ }^{30}$ - generally concentrated on beaches, museums, churches, and visits to "typical towns." 31

In later years, the national legislature passed a package of tax incentives, delivered through ICT, for large-scale tourism investment in 1985, including moratoria on property taxes and import duties for construction materials and vehicles. These incentives did not apply to smaller-scale enterprises, which would soon include most ecotourism developments, ${ }^{32}$ and even where they did, the government sometimes revoked the privileges prematurely. ${ }^{33}$ Tourism policies were often not consistent; for example, new visa legislation in 1986 created high 
administrative barriers to tourist entry. ${ }^{34}$ The ICT tried to involve the private sector in its decisions by creating a joint Tourism Marketing Committee in 1986, but alienated the entrepreneurs by spending the entire budget it had promised the committee, which resigned en masse. One such entrepreneur stated that he "refuse[d] to be part of an organization (ICT) dedicated to the destruction of foreign tourism in Costa Rica...”35 Once ecotourism had taken off, its advocates regularly denounced the ICT's lack of interest in the category, and its willingness to seize on "green" rhetoric while speeding the approval of large and environmentally destructive developments like the beach resorts at Playa Tambor and Papagayo. ${ }^{36}$

The growth of all varieties of tourism was, however, promoted by a level of political stability which set the country apart from its neighbors. Costa Rica had a long tradition of national elections and suffered few disruptions in the democratic selection of presidents after $1920 .{ }^{37}$ The major exception was a civil war in 1948, in which the "founding father" of modern Costa Rica, José Figueres Ferrer, utilized his temporary rule to abolish the military, nationalize the banks, weaken Communist militancy, and insist upon free elections after eighteen months of stabilization. In the following decades, Costa Rica alternated peacefully between presidential administrations of Figueres' party (PLN) and several opposition parties. Both the PLN and the opposition pursued economic policies based on state-led social development, partial industrialization, and continued agricultural exports. ${ }^{38}$

Following Costa Rica’s severe debt crisis in the late 1970s and early 1980s, both factions embraced privatization and other liberalizing reforms. During this difficult period of adjustment, demilitarized Costa Rica avoided the civil wars and dictatorships which engulfed its neighbors in Nicaragua and Panama. ${ }^{39}$ Though poverty and surrounding Central American instability 
disrupted Costa Rica’s still-nascent tourism industry in the early- to mid-1980s, it subsequently recovered, particularly after President Arias was awarded a Nobel Peace Prize in 1987. The prize provided a strong global signal of the country's commitment to peace, stability, and cosmopolitan and democratic traditions, and generated widespread interest in Costa Rica. ${ }^{40}$

By 1987, the country had also become well known among biologists and conservationists. Statutory and regulatory attempts at environmental protection dated back to the nineteenth century, but for decades execution was poor. ${ }^{41}$ Beginning around 1960, however, a series of public and private initiatives, both domestic and international, began to build up the scientific ideas and organizations and the national parks that would serve as a major impetus to ecotourism.

Scientists, NGOs, and the National Parks

The institutional basis for the scientific understanding of both the country's biodiversity and the need to protect it were laid quite early. The National School of Agriculture, integrated into the new University of Costa Rica in 1940, served as a locus for incipient conservation thought. $^{42}$ So, too, did the locally-based Inter-American Institute of Agricultural Sciences, established in 1942 and later known as CATIE, which would prove to be both a major source of scientific understanding of Costa Rican biodiversity and of conservation activism after $1960 .^{43}$ Biologists from Costa Rica and the United States soon established a series of other institutions that would educate a new generation of conservationists, and protect forests and wildlife in more than name only.

In 1959, drawing on U.S. philanthropy, the American herpetologist Archie Carr established the Caribbean Conservation Corporation, Costa Rica's first NGO, to provide funds for the protection of the sea turtle nesting beach at Tortuguero. ${ }^{44}$ Two other institutions founded 
by U.S. scientists are of particular significance for the later development of ecotourism, as they subsequently came to operate private reserves. In 1962, Leslie Holdridge, Robert Hunter, and Joseph Tosi established the Tropical Science Center (TSC). It was designed to conduct research in biology, agronomy and forestry, to consult with other organizations like CATIE, and to promote conservation through lobbying and direct land management. ${ }^{45}$ The following year, a consortium of six U.S. universities and the University of Costa Rica (UCR), guided by Rafael Rodríguez Caballero and Jay Savage, founded the Organization for Tropical Studies (OTS) to create a research station for their tropical biologists. ${ }^{46}$ These institutions and others would soon provide both education in biology and conservation, and also support for the creation of parks and private reserves.

Beyond Costa Rica, scientists in this era were developing the new ideas of conservation biology and biodiversity. The latter concept was intimately connected with scientists' and environmentalists' efforts to preserve tropical rainforests from at least 1972 onward. ${ }^{47}$ Biodiversity received a formal definition in 1980 and considerable attention and funding from U.S. universities, government agencies, and media after a series of publications and conferences such as the National Forum on Biodiversity. ${ }^{48}$ It connected especially well with the campaigns by various environmental NGOs including the World Wildlife Fund, Rainforest Alliance, and Rainforest Action Network during the 1980s to "Save the Rainforest." Building on the international orientation of environmentalism in the 1970s, these organizations worked to promote public awareness in the United States and Europe of developing nations' deforestation, through media reports and boycotts of companies whose supply chains were enmeshed with rainforest destruction. ${ }^{49}$ These NGO campaigns and media reporting on them unquestionably increased non-scientists' demand for travel to experience the rainforest in the 1980s, as they 
underwent a transition in public perception from hot and hostile jungles to rainforests that contained beauty and amazing biodiversity. Ornithology enthusiasts, too, soon followed the scientists and conservationists in expanding their international horizons in an attempt to add to their lists of bird sightings. While various companies began to cater to them after $1960,{ }^{50}$ local tour operators and private reserve owners in Costa Rica also found that birdwatching became one of their first strong market segments. ${ }^{51}$

Scientists and NGO activists were not the only émigrés concerned with preserving nature in Costa Rica. In the early 1960s, a couple named Olof Wessberg and Karen Mogensen, who had immigrated to Costa Rica from Sweden in 1954 in search of a natural, tropical paradise, secured funding from international conservation NGOs to protect the Cabo Blanco region of the Nicoya Peninsula. This became the first formally protected biological reserve in the country in 1965.52

Even earlier, in 1951, a group of American Quakers had moved to Costa Rica and begun dairy farming in the remote and sparsely populated mountain community of Monteverde. ${ }^{53}$ At the outset, they agreed to set aside a 500 hectare preserve of cloud forest to protect their watershed and out of inspiration for the area's natural beauty, naming it the bosque eterno (eternal forest). In 1972, a visiting graduate student named George Powell persuaded the TSC to solicit grants to purchase the land and neighboring forests, where incursions by squatters and loggers threatened the habitat of the resplendent quetzal, one of Costa Rica's most notable birds. Holdridge, Hunter, and Tosi also sought to cover the costs of protecting the area by generating revenue through visitation, and they built a field station for researchers, a visitors' center, and constructed a trail system and camping area. Scientific researchers sometimes volunteered their services in exchange for lodging, and the reserve became so popular with them and their students 
that it was the subject of a BBC documentary in 1978, which launched Monteverde's career as an ecotourism destination more broadly. 2000 visitors in 1978 became nearly 7000 in 1983 and reached a temporary plateau at 50,000 throughout the early 1990s. As a private reserve, Monteverde was able to charge visitors more than the national parks, and could generate enough revenue to pay for its upkeep even before the ecotourism boom. ${ }^{54}$

Holdridge had also bought some land on the Sarapiquí River north of the capital. In 1968, he agreed to sell the reserve, known as La Selva, to OTS for use as a tropical biology field station, and it was eventually connected by a corridor to the Braulio Carrillo national park. ${ }^{55}$ At least 1600 researchers stayed at La Selva between 1963 and 1988, but they also averaged more than three return trips per visitor, and a sample claimed a high level of influence on colleagues by word-of-mouth recommendations. ${ }^{56}$ Although La Selva provided only basic accommodations and permitted only narrowly limited tourist occupancy at a relatively high price, ${ }^{57}$ it helped to generate much of the awareness of the potential for nature travel to Costa Rica which was later directed to Monteverde, the national parks, and to commercial ecotourism enterprises. ${ }^{58}$ Altogether, “science tourism” generated an estimated \$1 million in revenues in 1976, and a decade later La Selva and OTS alone brought in \$1.5 million, or approximately 1.3\% of overall tourism spending in the country. ${ }^{59}$

Scientists not only catalogued Costa Rica’s biodiversity, promoted conservation, and protected and operated important private reserves. In pioneering classes and publications, the American biologist Kenton Miller of CATIE and his Venezuelan-Costa Rican student Gerardo Budowski articulated the notions of “ecodevelopment” and park-based conservation driven by revenues from responsible nature tourism. Miller and Budowski sought to combat a common attitude within the scientific and conservation communities that biologically valuable forest and 
marine areas should be cordoned off from human visitation. Instead, they argued in favor of a "symbiotic" relationship between non-extractive land use and nature protection, in which the former would generate revenue and lead to community acceptance of conservation in place of agricultural development. Through their influence on a young graduate student, Mario Boza, these ideas led directly to the national park system and the rise of ecotourism. ${ }^{60}$ Boza, inspired by Miller's teaching and a visit to U.S. national parks in 1967, developed a concrete plan for creating a park at Poás Volcano. He then took to Costa Rica’s daily newspapers to weigh in on the forestry law under debate in 1969 and to advocate seriously for a Costa Rican park system that would generate revenues from international tourism, much as in East Africa. ${ }^{61}$

The Costa Rican legislature did pass the Forestry Law in 1969, which envisioned a multiuse approach to the nation's forests embracing conservation, tourism, controlled extraction, and research. It explicitly allowed for the creation of the National Parks Department within the agriculture ministry, and the 27-year-old Boza became the head of the new department. ${ }^{62}$ Supported by Alvaro Ugalde, then still a student and later Boza's successor, and by influential political figures including Karen Figueres and later President Daniel Oduber, Boza began a process of declaring protected areas throughout the country and gathering the money to buy the land within them. At the end of the 1980s under a new leader, Alvaro Umaña, and recognizing the need to include local people in the financial benefits of the parks, the park service shifted towards the idea of sustainable development from merely nature protection. ${ }^{63}$ Sustainability became a central concern of the Costa Rican government in 1994, when President José Maria Figueres explicitly integrated it into the country's development strategy and reformed the forestry law. In the same year, the park service raised entrance fees from $\$ 1.50$ to $\$ 6.00$ for non- 
citizens to increase funds, ${ }^{64}$ and by 1998 , the state financed fifty percent of the park system's operating costs and the entrance fees financed thirty percent. ${ }^{65}$

Boza was always more enthusiastic than Ugalde and others about allowing tourism within the parks and using the revenues generated for their conservation. ${ }^{66}$ Some believed that the parks should be devoted to nature preservation alone, and looked askance at the perceived overdevelopment around some U.S. national parks. But there were also persistent funding problems, which intensified after 1980 and made the total exclusion of visitors unworkable. The bulk of the government's funds and international aid and donations were devoted to purchasing land within the declared park boundaries, leaving negligible budgets for park infrastructure and security. No lodges or guided tours, and few visitors' centers or trails, were made available anywhere by the park service. ${ }^{67}$

Without national parks, ecotourism in Costa Rica would have been a smaller and more precarious business. The parks were always a significant draw for private tour companies, making it worth investing to operate tours. As one entrepreneur put it in the early 1990s, a major reason why nature tourism was better business in Costa Rica than elsewhere in Central America "was that there were parks here, that there was good reason to believe that the resources would stay protected, so as to justify the investment of time and energy to get the parks known.”68 Nevertheless, without private accommodations and tour companies, few international or even Costa Rican tourists would have visited the parks and paid admission fees. As they benefited from the work of the scientists, conservationists, and park officials who had come before them, an array of environmentally-minded entrepreneurs helped secure those protected areas as well as private lands. The next section turns to these entrepreneurs. 


\section{Entrepreneurial Pioneers}

As travel to the parks and to non-profit private nature reserves like Monteverde and La Selva began to grow in the mid-1970s, a small number of for-profit nature tourism enterprises appeared as well, often on an informal basis within sharply limited geographic areas. Then, beginning in 1978, several tour operators and private reserve proprietors with strong environmental principles and international connections led the way in creating the commercial market, joined by a wave of other companies after 1985 when the country’s recovering economy and reputation for ecotourism began to attract a growing numbers of visitors. These early businesses were started both by Costa Ricans and by expatriates from the United States who had been drawn to Costa Rica in the 1970s.

Regardless of their nationality, the interests and attitudes of many of these entrepreneurs had been shaped by new cultural developments of the late 1960s and 1970s, including the counterculture, the increasing availability of international travel and adventure in the jet age, and the growth of popular environmentalism. The international counterculture, which reached beyond the small bohemian communities of earlier generations to embrace millions of educated, middle-class youths in the 1960s, emphasized the search for personal authenticity, opposition to materialism and the mores of elders and Cold War leaders, and the "unrealized spiritual and ideological demands" of prosperous youth and adults with access to leisure. ${ }^{69}$ Many of these desires found expression in international travel, which allowed for increased feelings of mobility, independence, and cross-cultural understanding, supported institutionally by the growth of youth hostel networks and relaxation of some visa and travel restrictions. ${ }^{70}$ They were also reflected in the growth of expatriate communities of young Americans and other nationalities who sought to build alternative lifestyles abroad, where they believed conditions were less constricting, ${ }^{71}$ and in 
the 1960s environmental movement. The latter was propelled not only by popularizations of ecological ideas like Rachel Carson's book Silent Spring (1962), but by the involvement of student protesters and middle-class women who shared countercultural goals of authentic living, communing with nature, and opposition to some forms of capitalism. ${ }^{72}$ As this section will suggest, ecotourism entrepreneurs—and particularly tour operators—often drew inspiration from these ideas in operating businesses that allowed them to share and promote their values.

Table 1 lists the major tourism enterprises in the country that were established for, or converted to, a primary focus on ecotourism between 1975 and the year 1993, which can be regarded as approximately the end of the truly pioneering era, and the start of the mainstreaming of ecotourism in the country. This section focuses on some of the earliest and most innovative tour operators. It examines how the entrepreneurs who founded them came to their environmental convictions and addressed a set of threats and challenges to expand their businesses and in the process facilitate the creation of the ecotourism industry. 
Table 1 Ecotourism Enterprises in Costa Rica, 1975-1993

\begin{tabular}{|l|l|c|c|}
\hline Name of Enterprise & \multicolumn{1}{|c|}{ Founder(s) } & \multicolumn{1}{|c|}{$\begin{array}{c}\text { Founder's } \\
\text { Original Nationality }\end{array}$} & $\begin{array}{l}\text { First Year Involved } \\
\text { in Ecotourism }\end{array}$ \\
\hline Papagayo Excursions & $\begin{array}{l}\text { Mary Ruth, Louis } \\
\text { Wilson }\end{array}$ & U.S. & 1975 \\
\hline Caminos de la Selva & Carlos Coles & Costa Rican & 1976 \\
\hline $\begin{array}{l}\text { Costa } \\
\text { Expeditions }\end{array}$ & Michael Kaye & U.S. & 1978 \\
\hline Tikal Tours & Bary Roberts & Costa Rican & 1978 \\
\hline Rara Avis & Amos Bien & U.S. & 1983 \\
\hline Horizontes & $\begin{array}{l}\text { Tamara Budowski, } \\
\text { Margarita Forero }\end{array}$ & Costa Rican & 1984 \\
\hline Ríos Tropicales & $\begin{array}{l}\text { Rafael Gallo, } \\
\text { Fernando Esquivel }\end{array}$ & Salvadoran & 1985 \\
\hline $\begin{array}{l}\text { Marenco Biological } \\
\text { Station }\end{array}$ & $\begin{array}{l}\text { Guillermo and Sergio } \\
\text { Miranda }\end{array}$ & Costa Rican & 1985 \\
\hline Selva Verde & Giovanna Holbrook & U.S. & 1985 \\
\hline GeoTur & Sergio Volio & Costa Rican & 1985 \\
\hline $\begin{array}{l}\text { Savegre Mountain } \\
\text { Lodge }\end{array}$ & Efraín Chacón & Costa Rican & 1986 \\
\hline Hacienda Baru & Jack and Diane Ewing & U.S. & 1987 \\
\hline $\begin{array}{l}\text { Arenal Observatory } \\
\text { Lodge }\end{array}$ & John Aspinall & Costa Rican & 1987 \\
\hline Tiskita & Peter Aspinall & Costa Rican & 1987 \\
\hline Hotel Si Como No & Jim Damalas & U.S. & 1993 \\
\hline Lapa Rios Ecolodge & John and Karen Lewis & U.S. & \\
\hline
\end{tabular}

Source: Author research

Early domestic tourism in Costa Rica had long focused on the country's beaches, and so it is perhaps unsurprising that the first internationally-oriented nature tour operators had their start along the Caribbean and Pacific coasts as well. In 1972, the Florida-born tourism entrepreneur Archie Fields established a company that later became one of Costa Rica's largest mainstream and nature tour operators in the 1980s under the name Swiss Travel. Fields also bought a wooden cabin that year on the mouth of the Colorado River, which he converted into a 
tarpon fishing lodge. Not yet a true ecotourism enterprise, the Río Colorado Lodge emphasized its air-conditioned comforts, but Fields was also involved in marine conservation efforts, offered early nature trips known as "Jungle Tours," and advertised widely to build a celebrity-studded clientele that brought Costa Rica to the attention of international sport-fishing tourists. ${ }^{73}$

On the Pacific coast, too, boating and fishing drew young, countercultural U.S. nationals seeking an alternative lifestyle in Costa Rica. Californians David and Cecelia Reid began offering group sightseeing cruises of the coastline and small islands in 1975, despite travel agents' skepticism. ${ }^{74}$ In the same year, two young Americans, Louis Wilson and Mary Ruth, first took patrons of the Hotel Tamarindo on boat trips up the Playa Grande estuary and on "turtle tours" to view the large nesting populations of leatherback sea turtles then present near Tamarindo. An informal operation known at first as "Papagayo Vagabonds," financed by an heiress friend and designed to support their lifestyle of surfing, fishing, and living in harmony with nature, the business was eventually incorporated as Papagayo Excursions. Although this might be regarded as one of the very first truly ecotourist ventures, it faced formidable challenges. As Wilson later pointed out, the local residents and San José travel agents initially mocked the tours' prospects. "We were considered to be the fringe," he observed, as the existing tourism industry expected international tourists to be interested in urban sights, but “they didn’t realize that what people really wanted to see was nature.” The ICT was no better, insisting that nature tours were unlikely to generate any interest. ${ }^{75}$

Nonetheless, Papagayo Excursions began to draw international tourists, especially from the United States, but also Canadians and Europeans, and even managed to expand visits from abroad during the early 1980s in the midst of recession by marketing their environmentallyfriendly catch-and-release deep-sea fishing expeditions. ${ }^{76}$ The turtle-watching tours remained 
Papagayo's focus until the second half of the 1980s, when larger companies captured market share, and numerous unlicensed boat tours operated by former turtle-egg poachers lowered both safety and ecological standards. ${ }^{77}$ Beginning in 1986, Wilson and the Costa Rican Marianela Pastor worked together to establish a wildlife conservation area at Tamarindo and constructed the Hotel Las Tortugas, building in protections for minimal impact on the beaching turtles. It opened to guests in $1991 .^{78}$ Ruth continued to run Papagayo, which possessed a seven-boat fleet and employed eighteen by 1992, but she had become disillusioned with the possibilities of ecotourism, reflecting on the growing ignorance of the tourists and the damage done by unlicensed ("pirate") operators and by overcrowding. ${ }^{79}$

A year after the first turtle-watching trips at Tamarindo, a young Costa Rican nature enthusiast and entrepreneur, Carlos Coles, established the first company in Costa Rica devoted to rainforest tours. Coles had studied biology and hiked the country's coasts and mountains in the early 1970s. He first began putting this familiarity with the land to use in guiding family friends who had come to visit from the United States, and inspired by a friend who had worked in wildlife conservation in Kenya, he decided to create and market tours that emphasized Costa Rica's flora and fauna. His company, Caminos de la Selva, or Jungle Trails, operated only in the dry months from December to April, and took three or four groups on multi-week camping excursions. With Coles as guide and two other employees, Jungle Trails drew mainly wealthy British tourists who had developed an interest in nature tourism. Coles continued his studies in the other months of the year, and the company did not operate year-round until 1986. Jungle Trails remained small, and although it survived into the 1990s, it employed no more than seven. In fact, between 1978 and 1980, Coles himself worked most of the year as a guide for another travel company engaged in promoting a new form of nature tourism: Costa Rica Expeditions. ${ }^{80}$ 
Michael Kaye founded Costa Rica Expeditions in 1978 as a whitewater rafting company and quickly developed his business into the largest ecologically-oriented nature tourism enterprise in Costa Rica. Kaye had been raised in Manhattan, but was devoted to the outdoors, and began whitewater rafting in California in the early 1960s. ${ }^{81}$ At first working as a road manager for 1960s music bands, ${ }^{82}$ Kaye and a partner then established a successful low-cost, high-volume rafting company called Mother Lode in California. After three years, Kaye sold his shares and subsequently traveled to Central America to explore new rafting opportunities in the mid-1970s. ${ }^{83}$ There he met a Salvadoran woman who became his wife, and the couple found themselves drawn to Costa Rica by its political stability, openness, and potential as a rafting destination.

When Kaye established Costa Rica Expeditions shortly thereafter, he partnered with a Costa Rican citizen in order to satisfy the governmental licensing requirement, eventually buying out this nominal partner when he himself became a Costa Rican citizen. He also hired a Salvadoran, Rafael Gallo, an engineer and river guide. Kaye, Gallo, Coles, and others scouted rivers around Costa Rica and led rafting parties. But Kaye recognized that the high-volume model he had used in California would not be workable in a country where rafting was as yet largely unknown. Using his expatriate status to his advantage, Kaye focused instead on drawing smaller numbers of North American tourists to an unfamiliar but highly promising destination and providing them premium service. He later noted that he "didn't have enough cultural knowledge, even with all the time in Latin America, to sell to this market” in the early years. ${ }^{84}$ Many local residents were also underserved owing to the firm's emphasis on small numbers and premium pricing. This left room for Gallo to leave Kaye's operation amicably and start his own 
ecologically sensitive rafting enterprise, Rios Tropicales, with partner Fernando Esquivel in 1985 to focus more on the domestic market. ${ }^{85}$

By 1985 Costa Rica Expeditions was much more than a rafting company. Kaye had quickly found that the U.S. and Canadian tourists he brought in wanted to see more of Costa Rica after several days' rafting. He had observed the potential for "natural history tours," or scientifically-guided forest hikes, when taking groups to cloud forests in Guatemala in the mid1970s, and saw them as an opportunity for new business. The risks such tours had faced in Guatemala-he had once scheduled a tour to an area that turned out to have been unexpectedly clear-cut-were obviated by Costa Rica’s system of parks and private reserves. So in 1979 he hired Jim Lewis, a U.S. biologist who had been consulting with the TSC, to become a guide and director of natural history tours. By 1980 Kaye’s company offered tours to the Santa Rosa, Corcovado, Chirripó, Tortuguero, and Isla de Coco parks, ${ }^{86}$ and by 1988 its staff of 50 included naturalists, ornithologists, entomologists, horticulturalists and other trained guides. ${ }^{87}$

Costa Rica Expeditions thus brought increased revenue to the parks and provided the guiding and accommodations services that the park service could not afford to budget. As demand grew rapidly, Kaye found it difficult to provide satisfactory accommodations for his tour groups owing to the lack of control over the service standards of local lodges. Consequently, when the opportunity arose to buy a hotel in Tortuguero where Costa Rica Expeditions had been sending clients, Kaye arranged a loan from a US-backed private bank and bought the hotel in 1986. ${ }^{88}$ Eventually the company vertically integrated by purchasing several other properties, including a hotel at Monteverde which it built in 1991 to guarantee lodging at the popular destination during the ecotourism boom. ${ }^{89}$ Kaye intended to invest in long-term operations in 
Costa Rica, rather than to repatriate his profits to the United States, and the purchase of hotels was one step in that direction. ${ }^{90}$

By 1991, some $75 \%$ of Kaye’s 20,000 annual clients came to Costa Rica for natural history ecotours, spending an average of $\$ 148$ a day in the country. ${ }^{91}$ In 1994 , his company had 180 employees, the great majority of them Costa Ricans. ${ }^{92}$ It continued to grow throughout the 1990s, taking advantage of the opportunities for direct marketing provided by the Internet by becoming a partner in one of Costa Rica’s first Internet service providers in $1994 .{ }^{93}$ Although it was widely regarded as a green company and Kaye became involved with TIES, local chapters of environmental NGOs occasionally criticized Costa Rica Expeditions for its relatively high volume. On one occasion, the Rainforest Alliance ecotourism project even refused to rate the company in its first green travel certification program (discussed below) over a difference of opinion about the "social” component of responsible ecotourism. ${ }^{94}$

Nonetheless, Kaye’s early environmentalism, which was at first aesthetically and then ecologically motivated, had strongly influenced his view of how nature tourism should be conducted. He had spent significant time at Yosemite National Park, and shared the growing countercultural consciousness that environmental problems required active protest and opposition. He became involved with Martin Litton, a fellow rafter, Sierra Club board member, and important figure in environmentalist circles. Kaye particularly came to share Litton's longstanding opposition to river dams for their destruction of riparian ecology and natural beauty, despite the highly positive common opinion of hydroelectric projects at that time. He opposed several dams on California rivers, but the protests merely delayed construction, which was the major factor prompting Kaye to sell his shares in Mother Lode and leave the state. Not for the last time, Kaye's environmental views and his business interest in protecting the rivers for 
rafting were aligned. ${ }^{95}$ After moving to Costa Rica, Kaye said of his vision of the industry in a 1980 interview that "Tourism should contribute to, rather than exploit [the land]." ${ }^{96}$ He later argued explicitly that operating in an environmentally and culturally sensitive way made both business sense and ethical sense. Costa Rica Expeditions hired local people as guides and installed solar-powered heaters and sound waste treatment systems such as biodigesters at its properties. ${ }^{97}$ Over industry opposition, the company argued that park fees should be raised in the 1990s to increase funds for conservation, and it donated more than $\$ 100,000$ to the parks and NGOs for environmental protection, which Kaye regarded as "money well spent, keeping our product attractive and worthwhile.”98

Not long after Costa Rica Expeditions diversified from rafting into ecotourism, it was joined by other travel companies run by Costa Ricans with international connections. As Kaye led his first rafting groups in 1978, the 28-year-old Costa Rican Bary Roberts was pondering how to expand inbound tourism without generating destructive overdevelopment. Roberts was the son and grandson of Protestant missionaries with roots in Canada, who had discovered a passion for travel in North America, Africa, and Europe during the 1960s. As a teenager, he had shared the counterculture's wanderlust to the degree that he had hitchhiked from Costa Rica to Los Angeles, and sought, as he remarked, to be "open to the world." While completing his degree in economics at the University of Costa Rica at the beginning of the 1970s, he took a position with Pan Am, but also cultivated a farm. He enjoyed working in the travel industry, the international orientation of which aligned with his personal goals and values, and when given the opportunity in 1975 to sell his farm in exchange for a small existing travel agency known as Tikal Tours, he took it. ${ }^{99}$ 
At the time, Tikal's principal business involved ticketing Costa Rican outbound tourists and packaged bus tours to sights elsewhere in Central America, but Roberts sought to bring more international visitors to Costa Rica. He had a cautionary experience in 1976, however, when a trip to the Spanish town of Sitges revealed the damage caused by intensive beach tourism in the decade since his first visit there. Motivated by his family’s Christian vision of stewardship and by his friendship with Mario Boza and Alvaro Ugalde, Roberts was determined to avoid creating a new Sitges in Costa Rica. Through his step-brother in the government, he arranged a meeting in 1978 with Maurice Strong, the Canadian businessman and organizer of the first U.N. conference on the environment in Stockholm in 1972, who was visiting Costa Rica. ${ }^{100}$ Strong had bought some beachfront property on the Caribbean coast which he would later develop into a resort, creating a minor controversy during the 1992 U.N. Earth Summit in Rio de Janeiro. ${ }^{101}$ But at the time of his meeting with Roberts he sought to preserve the property from destruction and had incorporated a company to hold the land which he named Ecodesarrollos S.A. (EcoDevelopment). Roberts impressed Strong with his vision of increasing inbound tourism without causing cultural or environmental damage, and to encourage the younger man, Strong offered him an investment equal to a quarter of the value of the company. The Canadian would serve as a silent partner until Roberts reacquired the shares from Ecodesarrollos in $1992 .{ }^{102}$

Buoyed by this investment and by what he learned from Strong about environmentallyfriendly development, Roberts weathered the threats to tourism from the recession and Central American instability of the early 1980s. At Strong's suggestion, he began to explore the idea of “ecological tourism” for inbound tourists. ${ }^{103}$ “There was a lot that could be done that was not being done, particularly in the way of educating the clients themselves, and creating a positive impact on the [natural] areas instead of destroying them like most tourist centers,” Roberts 
reflected in $1992 .{ }^{104}$ He attempted to develop nature tourism packages for international clients, and taking a cue from the name of Strong's enterprise, Tikal was the first travel company to use the word "ecotourism" in Costa Rica. Indeed, Roberts registered the term as a trademark in 1985, as the general concept was becoming popular. The trademark led to controversy with other tour operators and TIES, who regarded it as an attempt to co-opt a common enterprise, while Roberts argued that it was a way to protect the concept from being watered down by widespread use. $^{105}$

Roberts also faced skepticism from some competitors and environmental organizations over his other innovation during the mid-1980s: the introduction of ecotourism itineraries to large chartered tours that had previously been focused on beaches and urban sights. For several years, the Smithsonian Institution, National Geographic, the World Wildlife Fund, the Audubon Society, and numerous U.S. universities had brought small groups of people to Costa Rica, generated business for Tikal, Costa Rica Expeditions, and other firms, and subsequently advertised Costa Rica's natural wonders in their magazines and television programs. ${ }^{106}$ "But," noted Roberts, "the great majority of the people are not getting to see" what the environmental organizations' members saw. He sought to create a "mass production [form of] tourism that could present the natural resources, but at the same time be a way of funding and protecting [them], and be a way of raising consciousness of the ecological problems.” ${ }^{107}$

In 1986, Roberts convinced the Canadian wholesaler Fiesta Wayfarers Holidays Ltd., which at the time brought 13,000 clients to Costa Rica annually on chartered flights, to include eco-tours operated by Tikal in its itineraries. The following year, Tikal managed about a third of Fiesta's business in Costa Rica, providing its own guides and buses but subcontracting hotels. Roberts named the tours "eco-safaris," and offered four throughout the country, including one 
devoted to rafting and horseback riding. The clientele was quite different from those traditionally attracted to ecotourism: Roberts occasionally had to explain that there would be no elephant sightings on a Costa Rican eco-safari. They expected greater comfort, and Roberts eventually built his own eco-lodge at Lago Coter in order to exert greater control over the quality of the experience while maintaining ecological standards. At first, Tikal's competitors saw Roberts' approach as conceding too much to a purely "commercial” form of ecotourism, and he was not able to generate as much new business from environmental groups as he had hoped. ${ }^{108}$ As ecotourism grew in the 1990s, this view of Tikal began to change even as the company drew ever-larger numbers of tourists from Canada, the United States, and Germany, and competitors would later view Roberts’ enterprise as a genuine green company rather than a "greenwasher.” 109

Still another path to leadership in the ecotourism industry was traced by Tamara Budowski and Margarita Forero. The two women, both aged twenty-four, established Horizontes Nature Tours in 1984. Budowski was the daughter of the forest biologist Gerardo Budowski and a Panamanian mother, and Forero’s grandparents were Colombian and German immigrants to Costa Rica. ${ }^{110}$ When young, Budowski had lived in Berkeley, California, as well as in Paris and Switzerland, and changing schools and languages with such frequency led her to feel "more a citizen of the world than a citizen of any country" and to appreciate the emphasis on cross-cultural harmony and understanding that marked the 1960s counterculture. She later described herself as "very much influenced" by the counterculture, the peace movement, and the environmental movement of that era. ${ }^{111}$ Her father's work also exposed her from an early age to biological and ecological studies, and particularly to the developing idea of biodiversity, as well as to the connected normative drive to protect threatened natural environments, all of which she later pursued at university. Her childhood was, moreover, marked by prolonged and repeated 
international nature travel. ${ }^{112}$ While abroad, she later recalled, "we would go to national parks in different areas of the world, like northern Africa or Kenya, Tanzania, Sri Lanka, [and] Latin America. So I grew up, in a way, doing ecotourism." ${ }^{113}$ Both Budowski and Forero broke with family expectations in order to work in the travel business. They met and became friends at the technical college in Cartago, which offered a new degree program in tourism, camped in the Costa Rican national parks, and then pursued further business training abroad. Budowski studied marketing in Miami, where she was alerted to the problems of mass tourism development, and Forero specialized in tourism administration Salzburg, Austria. ${ }^{114}$

Upon their return to Costa Rica, Budowski worked at the student travel organization OTEC for a year, while she and Forero traveled to various Costa Rican parks, enjoying the adventure of backpacking and planning the opening of their own conservation-oriented travel company throughout $1983 .{ }^{115}$ Lacking capital, they secured an outbound-only license and initially focused on ticket sales as they continued to research and explore destinations for future inbound clients. ${ }^{116}$ Throughout 1984 and 1985, they built their capital and reputation and developed an alliance with Sergio Miranda, a family friend of Forero who was beginning to develop the Marenco private reserve near Corcovado National Park (discussed below). This arrangement, and Miranda's financial resources, allowed Budowski and Forero to devote themselves to "leading naturalists to the country's most attractive wildernesses," while the Mirandas gained a channel through which to market Marenco. ${ }^{117}$ As Budowski later reflected, “They didn’t have the travel knowhow, but they had financial resources and they had a hotel. We had the knowhow—we didn’t have money, and we didn't have other assets, and it seemed like the perfect alliance.... And we created Horizontes together." ${ }^{\text {"18 }}$ Horizontes began offering nature 
tours of the national parks and Monteverde to the wholesale travel trade, primarily in the United States, in $1986 .^{119}$

In its first decade, Horizontes was heavily reliant on group business from the United States and Canada, creating tours for conservation and educational organizations. Budowski estimated that such groups made up about $75 \%$ of their business in 1992, at which time the firm had expanded to employ 28 full-time staff, a majority of them women. The attraction for the conservation organizations was not only Horizontes' well-scouted destinations and intimate knowledge of Costa Rican business customs which allowed for minimal disruptions, but also the firm's commitment to environmentalism. Horizontes donated to numerous local causes, including the national zoo, as well as scientific and conservation organizations including the TSC, OTS, CCC, and Centro de Estudios Ambientales. It offered a free training course to forty guides from all companies to improve the level of biological and ecological knowledge passed on to tourists. ${ }^{120}$ In 1992, it combined with Costa Rica Expeditions to establish a $\$ 25,000$ fund to meet some of the needs of park service personnel as a way of helping ensure the parks' continuing viability. Like Kaye, Budowski publicly argued in the early 1990s that environmental sensitivity and the protection of nature from overdevelopment was simply good business. $^{121}$

In the 1980s and 1990s, Budowski saw private business and the non-profit scientific organizations like the TSC and OTS as building the new ecotourism industry largely in the face of indifference from the government, especially the ICT. ${ }^{122}$ She argued that for the first decade of ecotourism, "it was private enterprise (hotels, lodges, travel agencies) that got behind it, both nationally and internationally, using advertising and such public relations tools as promotional trips to attract attention to Costa Rica's natural riches,” and she particularly credited the airline 
LACSA. ${ }^{123}$ Although she later interpreted this positive attitude toward the private sector as a function of 1980s "yuppie” culture, she and Forero also tried to cultivate a company culture that prioritized values like sustainability, philanthropy, and trust, and thus had much in common with the values they detected in their clients. ${ }^{124}$ Budowski observed at the 1988 conference of the International Union for the Conservation of Nature that the idea of ecotourism arose from the "search for profound and enriching experiences that characterized the decade of the sixties," which came especially to embrace "outdoor activities" in the 1970s and health, natural foods and exercise in the 1980s. ${ }^{125}$

In short, tour operators like Papagayo Excursions, Caminos de la Selva, Costa Rica Expeditions, Tikal, Horizontes, and Sergio Volio's GeoTur were major actors in the creation of Costa Rican ecotourism. Whether their founders were Costa Rican or American, they sought to incorporate the values they had drawn from the countercultural, spiritual, or environmentalist ideas and experiences of their youth into the guiding purposes of their firms. They also possessed international connections that allowed them to market effectively to potential North American and European consumers interested in the fate of the rainforests and of wildlife. Their businesses in turn brought the national parks much-needed funding through an ever-increasing stream of such international visitors.

\section{Eco-Lodges and Private Reserves}

None of the tour companies could provide sufficient lodging for guests in all of their areas of operation. They relied, as a result, upon the growth of private reserves and eco-lodges to house their clients and supplement trips to national parks. Private reserves in turn drew many ecotourists to the country on their own, and as they directly conserved natural areas outside of the national parks, they often served as "buffer zones" to protect the territorial integrity of the 
latter. These reserves and eco-lodges were often connected with scientific research, but they frequently evolved to offer their own tours of their private land and local areas, especially when in the vicinity of national parks. Many such reserves opened to the public at the same moment, between 1986 and 1987. ${ }^{126}$

The first of these concerted efforts to establish a for-profit reserve in order to protect a local area was that of the U.S. biologist Amos Bien. ${ }^{127}$ Bien had studied biology at the University of Chicago, where he had initiated a community recycling program in the early 1970s. Inspired by a course in tropical botany that had introduced him to the deforestation crisis, he later enrolled in a graduate program that brought him to Costa Rica through OTS. While studying at La Selva, Bien began looking for a way to align the incentive to preserve the rainforest with continued economic development. ${ }^{128}$ In April, 1983, he decided to open the Rara Avis Lodge as an experiment to prove that intact rainforest could be more profitable than clear-cut land. He formed a Costa Rican corporation, bought a 485-hectare property in 1986 with both bank loans and equity capital, and developed rudimentary accommodations in a former prison building on the grounds. Bien sourced food and other products locally, and employed mostly community residents - 14 full-time in 1992, and four part-time-and gave them an equity stake in the business after two years' employment. ${ }^{129}$ Rara Avis was estimated to have brought around $\$ 80,000$ a year to the neighboring town of Horquetas in $1991 .{ }^{130}$

Bien welcomed this involvement by the local community because he felt that "if the chainsaw wielders were not part of the project, then it would never work.” He brought in students and birdwatchers as guests beginning in 1986, built a lodge that could house 32 in 1989, and added running water but never electricity outside the lodge's common space. Rara Avis attracted guests from the United States, Canada, Germany, Switzerland, the Netherlands and 
Scandinavia throughout the late 1980s and 1990s, provided discounts to draw Costa Ricans, and was an early convert to internet marketing in 1995. It offered guided hikes, birdwatching, a small orchid garden and butterfly farm, and through the assistance of biologist Don Perry of OTS, a climbing cable-car system with platform viewing opportunities at the top of the canopy. ${ }^{131}$ Perry received the income for his device, but it served as a marketing tool to put Rara Avis on the map from the late 1980s until 1994, when Perry relocated the system to a more accessible site than Bien’s remote lodge, and started a larger, \$2 million eco-friendly educational enterprise under the name "Rainforest Aerial Tram.” 132 Without Perry’s contraption, guest numbers at Rara Avis peaked in 1996 and subsequently fell modestly. Nevertheless, the continued survival of the enterprise as a business alongside its success in conserving the property bore out Bien’s ecotourism hypothesis.

As Bien was raising capital to buy the original Rara Avis property in 1985, the Costa Rican Miranda family was exploring the possibility of bringing tourists to their remote landholdings on the Osa Peninsula. Guillermo Miranda had bought 400 hectares of primary forest from the government in 1974, intending to start a cattle ranch. He cleared three or four hectares before coming to the conclusion that the property and its wildlife were too beautiful and unique to destroy. ${ }^{133}$ Corcovado National Park was established bordering their property in the following year, and when the Mirandas traveled from San José to visit it in the late 1970s and early 1980s, they often encountered biologists seeking transportation and lodging in the area of the park. Recognizing an unserved market, they overcame their doubts about the viability of a business in such a remote location and decided to establish Marenco Biological Station. The name was chosen so as to attract biologists seeking to work in Corcovado or the nearby Isla de Caño National Park, and groups of students doing field work for tropical biology courses. ${ }^{134}$ 
Nevertheless, through the connection with Horizontes that Guillermo Miranda's son Sergio developed in the mid-1980s, the Mirandas began to attract non-academic American clients interested in ecology. Starting with small groups of 55-65 year-old professionals and eight bedrooms with shared bathrooms, ${ }^{135}$ Marenco saw a major increase in tourist visitation beginning in 1988, and by 1992 they could offer 25 separate rooms, a main lodge building with a restaurant and shop. ${ }^{136}$ In these years, they received bookings through Horizontes but also marketed both the region and their lodge at trade shows, and advertised in U.S. magazines until the sudden popularity of Costa Rica made advertising an unnecessary expense. ${ }^{137}$ The alliance between Horizontes and Marenco was an easy one, as both were committed to the environmental cause. The Mirandas saw providing buffer-zone protection for Corcovado as one of the major purposes of their enterprise, offered three regular nature excursions in their reserve and the nearby parks, and sought to include as many local residents as possible among their 60-70 highseason employees. The family determined that it would be better to offer more luxurious accommodations than to expand the footprint of their property, which remained at 25 rooms in 2001 despite demand from visiting cruise ships. ${ }^{138}$

Inland to the north, in the quetzal-filled cloud forest of San Gerardo de Dota, the Chacón family also perceived an opportunity brought about by visiting biologists. Efraín Chacón and a group of hunting companions had first explored the Río Savegre Valley in 1954, when it was untouched primary forest. They constructed a dirt trail to the Pan-American Highway in 1961 and Chacón brought his family to build a house and to farm and fish for trout. ${ }^{139}$ The Chacóns became accustomed to feeding visiting fishermen, and in 1971 they built a small cabin for guests, shortly followed by two others. Although they could not advertise, word spread and tourism gradually supplanted agricultural pursuits as their primary business. In 1978, two 
researchers from Harvard University were impressed by the profusion of quetzals in the area, published photographs in the United States, and the Chacóns began to host increasing numbers of American birdwatchers. They formally incorporated their business, and registered with the ICT under the name Albergue de Montaña Savegre (Savegre Mountain Inn) in $1980 .{ }^{140}$

Two years later, Efraín Chacón came to an agreement with a U.S. university to build a field station on the property for visiting biologists and students. ${ }^{141}$ When the travel companies began searching for destinations at this time, they contacted the Chacóns, who provided accommodations for Costa Rica Expeditions, Horizontes, and Caminos de la Selva, among others. ${ }^{142}$ The strong interest of the visitors and conversations with biologists caused the Chacóns to see their lands through an environmentalist lens for the first time. Efraín, who had originally had to live in a cave when settling the area, adapted very quickly to the conservationist convictions expressed by foreign guests who had never known a comparable level of need. He recognized that ecologically sound tourism could be beneficial on several fronts. "If we know how to conserve the forests, and work with the least impact possible,” he later remarked, Savegre would maintain both its natural resources and its visitors. ${ }^{143}$

Another of the first eco-lodges was also the work of individuals who had no initial commitment to conservation. The American Jack Ewing arrived in Costa Rica to work in the cattle business in 1970, was soon joined by his wife Diane, and by 1976 came to manage a ranch for a U.S.-based investor group. Called Hacienda Baru, it was a 330-hectare property with three kilometers of beachfront on the Pacific Ocean. ${ }^{144}$ Ewing became a partner with a one-seventh interest in the land in the late 1970s, ${ }^{145}$ and engaged first in ranching and then farming until 1982. But while living on the property, he grew increasingly interested in the surrounding primary forest, and noticed how modern agriculture led the plant-life and wildlife to become "out 
of balance." ${ }^{146}$ He was moved by the killing of a beautiful ocelot and ended hunting on the property, which gave him a reputation as an environmentalist. "And at some point-I don't remember exactly when-I guess I just stepped into the role," he later reflected. He and Diane joined the Costa Rican conservation organization known as ASCONA, and contacted OTS to seek reforestation advice. ${ }^{147}$

Beginning in 1982, the Ewings secured the region's first zoning plan to protect the property, beachfront, and ecologically sensitive areas such as mangroves. Their neighbors' interest in beachfront tourism led them at first to look askance at tourism in general. ${ }^{148}$ But after some acquaintances insisted on paying for a guided hike in 1987, the couple began to discuss the idea of running rainforest tours for profit. Both local property owners and Ewing's own partners thought the idea ridiculous, ${ }^{149}$ but made no objection. Hacienda Baru first catered to foreign tourists in 1988, bringing in $\$ 4500$ in its third year and becoming profitable in $1991 .^{150}$

Hacienda Baru’s commercial success helped change the local property owners' attitudes toward conservation, and several sought to start their own ecotourism businesses. ${ }^{151}$ Expatriate U.S. businessman Steve Stroud bought out the other investors and provided further capital for ecotourism development. The Ewings added four new cabins in 1994 for visitors wishing to stay overnight. Jack Ewing continued to offer guided rainforest tours, horseback riding and a "Night in the Jungle" tour with camping on a raised platform, ${ }^{152}$ but added a canopy tour that involved climbing into the treetops in 1993, and a zip-line tour in 2000. Stroud and the Ewings secured National Wildlife Refuge status for the property in 1995, further improving its reputation as an ecotourism destination, and drew a steady stream of American and especially European visitors after the advent of internet marketing. ${ }^{153}$ "It's not going to make us rich,” Jack Ewing remarked in 1992, but by providing access to a sizeable private rainforest to biologists, students, and 
limited numbers of tourists, “we can guarantee the people something they can't get in the national parks. We can guarantee them that they're not going to see anybody else when they're in there.”154

Rara Avis, Marenco, Savegre, Hacienda Baru, and equivalent reserves and lodges provided the accommodations necessary for ecotourists who visited nearby parks, increasing the flow of travelers to Costa Rica while remaining devoted to environmental sustainability. The entrepreneurs who converted these businesses to ecotourism were, on balance, motivated less by countercultural and environmentalist values or enthusiasm for travel than their tour operator colleagues, and more by the importation of American biological and ecological scholarship and the need to serve visiting scientists, bird-watchers, and subsequently broader categories of ecotourists. They did, however, adopt the conservation orientation of most visiting naturalists, and became proud of the fact that their businesses directly protected valuable or representative lands and supported some scientific research.

\section{Economic and Societal Outcomes from Ecotourism Industry}

Ecotourism delivered significant economic and environmental benefits to Costa Rica. Tourism became Costa Rica’s principal export and source of foreign exchange in 1993, surpassing bananas, and remained so apart from a few years in which it was outpaced by microchip production from an Intel plant. ${ }^{155}$ The category was estimated to represent a cumulative investment of nearly \$1 billion over the years from 1986 to 1998, and it employed ten percent of Costa Ricans in 2000, ${ }^{156}$ while large majorities of the nation's tourism businesses remained small-scale and located in rural areas. ${ }^{157}$ Even as tourism grew, public and private parks and reserves together protected over a quarter of Costa Rica's land area. ${ }^{158}$ A virtuous circle of investment and new policies played a role in the recovery of Costa Rica's forests, which 
had been restored to cover more than 40 percent of the country's land area by $2002 .{ }^{159}$ The cohort of small but successful entrepreneurs in ecotourism exercised a strong demonstration effect, proving to skeptics in government and the agricultural sector that nature preservation could be commercially viable.

Outcomes were not, however, wholly positive. Conventional tourism flourished alongside ecotourism. There was continued growth of large international hotel chains in the country. ${ }^{160}$ Unsustainable resort projects continued to threaten the beaches of Guanacaste and elsewhere. The sudden interest in the environment that swept over the country led to an overuse of the terminology of ecology, providing incentives to engage in "greenwashing," or making false, opportunistic claims of environmental benefits. In terms of Richard Butler's Tourism Area Life Cycle model, Costa Rica as a destination had passed from the "exploration" and "involvement" stages, in which the "science tourists" and committed entrepreneurs had shaped the industry, into the "development" stage of large-scale corporate and governmental involvement. It thereby risked the possibility that the new entrants to the market, driven solely by profit or by the desire to increase national tourism revenues, would overdevelop the industry, jeopardizing the country's natural resources and the position of the pioneering firms. ${ }^{161}$ Even for entrepreneurs whose environmental convictions were integrated into their companies' principles, the influx of new and less well informed tourists created challenges in providing good service and concerns about the potential damage caused by an increase in scale.

Competing for inexperienced international customers with enterprises that offered green rhetoric but little substance was fraught with risks for the ecotourism pioneers. Many individuals both inside and outside of the industry consequently became interested in rating and certification schemes in the 1990s. Richard Holland and Chris Wille of the Rainforest Alliance developed 
voluntary guidelines for ecotourism enterprises in Costa Rica, and distributed them in 1990 at the country's annual tourism trade show, Expotour, whose theme that year was ecotourism. The guidelines consisted of a code of responsible tourist conduct with a commitment to environmental education, and company compliance was to be monitored by student volunteers in exchange for publication in a "recommended" list. ${ }^{162}$ Beatrice Blake and Anne Becher, the authors of The New Key to Costa Rica, the most influential early English-language guidebook to the country from the 1970s to the 1990s, also decided to rate accommodations on their success in achieving sustainability. After conducting surveys for the 1992 and 1994 editions, they listed hotels and lodges that received passing scores on environmental management and social engagement in the New Key as sustainable accommodations, and subsequently adopted a threetiered rating system for those listed. ${ }^{163}$ Several other systems appeared under the aegis of organizations located outside of Costa Rica, including the International Youth Hostel Federation (in 1991-1994) and the International Ecotourism Society (1993-1995). ${ }^{164}$

The most important effort at developing standards and certification for sustainable tourism in the country came in the mid-1990s through a cooperative effort between the ICT, the industry, and NGOs. By 1992, the ICT was considering establishing its own certification system, first known as the Green Seal (Sello Verde). ICT officials Marco Picado and Rodolfo Lizano, Bary Roberts, who had become vice president of the ICT under the new government in 1994, Lawrence Pratt from the Central American Institute for Business Administration (INCAE) and Alfio Piva of the National Biodiversity Institute (INBio) then developed the "Certification for Sustainable Tourism” (CST) from 1994 to 1997. The first version of CST was made available for hotels in 1997 and for tour operators in 2001, and it offered on-site inspections by accredited auditors to verify performance in such areas as water and energy consumption, 
emissions, waste management, effect on flora and fauna, and impact on the local community. More than one hundred hotels applied for CST certification by $2001 .{ }^{165}$

Despite its popularity, CST was also criticized. Roberts, Pratt, Piva, and others were disappointed when a change of government led the ICT to take full ownership of the CST, closing out a continued partnership with the business and environmental NGO communities. ${ }^{166}$ Beatrice Blake, and some small and mid-size tourism entrepreneurs, complained that the CST's requirements were unnecessarily expensive and time-consuming, and assisted larger companies at the expense of the more innovative smaller ones. ${ }^{167}$ These criticisms were indicative of some of the challenges of codifying what sustainable tourism actually meant, and more broadly of the incentive for certification schemes which sought to be widely adopted to set metrics at levels which many participants had a realistic chance of meeting. The same issues bedeviled certification of many green industries from organic wine to building and construction. ${ }^{168}$

The new wave of tourists who were the intended beneficiaries of the CST and other certification systems included demographics that had not ventured to Costa Rica in prior years. They brought the opportunity to extend the educational mission of ecotourism, but there were also trade-offs. In the 1990s, so-called "soft" nature tourists included those interested in nature but seeking comfortable accommodations, and those who traveled to Costa Rica because it had become fashionable, yet who had little interest in nature beyond beaches. The former especially created opportunities for boutique hotels and luxury ecolodges, which were quite different in character from early rustic lodges, but equally committed to environmental principles.

Among the most innovative and architecturally dramatic were the Lapa Rios Ecolodge established by Karen and John Lewis, ${ }^{169}$ and Jim Damalas' Hotel Si Como No, both of which opened in 1993 after cooperation between American expatriates and Costa Rican architects, 
followed a year later by Hotel Punta Islita. The entrepreneurs behind these hotels had much in common with the earlier ecolodge pioneers. For instance, Damalas was a Californian and member of the Sierra Club who had been visiting Costa Rica periodically since 1974. He worked in Hollywood but also maintained a farm near Manuel Antonio National Park and a strong interest in landscape architecture. Making use of the tax incentives provided by the 1985 tourism law, he decided to build a hotel that would fit into the landscape while providing an impressive vista for his guests to replicate the experience he had had when visiting the property for the first time in the 1970s. In 1992, Damalas and architects Ronald Zurcher and Jaime Rouillon began constructing villas along the property's hillside overlooking the Pacific coast, removing no trees and retaining corridors for the movement of monkeys and other animals while substituting natural airflow for energy-consuming air-conditioning. The hotel also provided easy access to Manuel Antonio National Park, generating revenue for the park service, and Damalas insisted on keeping it free of television sets, air conditioners, and noxious chemicals and detergents. ${ }^{170}$

The green boutique hotels established by Damalas and the Lewises were designed to appeal to "soft" ecotourists—principally couples at Lapa Rios and families at Si Como No—but still aimed to promote education and rainforest tours nearby. As the advent of the Web during the 1990s opened up new booking travel options, the challenge for such businesses was to remain committed to sustainability even as internet comparison shopping sites focused primarily on price and tourists displayed decreasing interest in environmental quality. ${ }^{171}$ Even the most ecologically sensitive international tourists still arrived by air, with all of the associated problems of burning fossil fuels. 
Tour operators shared growing skepticism about what could be achieved. Mary Ruth of Papagayo Excursions reflected as early as 1992 that "What we started off to do, which was [based on] a love of Tamarindo and the nature, and the beauty—it has definitely been exploited and I have had to reevaluate how I feel about it because you can’t stop it." ${ }^{\text {172 }}$ By the early 2000s, Tamara Budowski took the lack of interest of the new ecotourists, the building of golf courses, the polluting practices of cruise ships and the commercialized killing of sharks and other animals as a sign that "despite all the efforts," ecotourism "wasn't working." She continued to run her business until 2008, but found herself troubled by it and retired to seek new horizons in esoteric religion and the global eco-village movement. ${ }^{173}$ Michael Kaye, too, saw no sign of client interest in the sustainability practices of tour operators or hotels unless the client was already seriously engaged in environmental causes. Tourists were "happy to get outraged if they think you are doing something wrong," but their actual purchasing patterns and company reviews reflected no desire to put sustainability at a level with price or comfort. Even the international bodies that singled out particular firms for environmental awards-including Costa Rica Expeditions—operated on the basis of personal connections rather than merit, he concluded. ${ }^{174}$ While the multiple gains from ecotourism were evident, by the early twenty-first century the trade-offs and limitations had also become clear.

\section{Conclusions}

By 2002, when the United Nations declared the "International Year of Ecotourism," Costa Rican ecotourism was an impressive success held up as a worldwide model. The country had been rebranded as a natural paradise. The category raised employment and generated considerable income flows. 
This working paper has argued that the ecotourism cluster in Costa Rica was a cocreation of the public, private, and tertiary sectors. Forest and wildlife biologists and other students of ecosystems and biodiversity were vital at the start of the process, as were national and international conservation NGOs. Without the scientists' and conservationists' work, little would have been known about Costa Rica's rainforests and their denizens, few if any national parks would have been created, and little international interest would have arisen for trekking through steamy tropical jungles before they disappeared in the name of progress.

The private sector was also pivotal. Without entrepreneurship, much of it expatriate, the underfunded park service and NGOs alone would not have been able to bring sufficient numbers of tourists to Costa Rica to contribute to the maintenance of the parks. Multiple small-scale entrepreneurs helped ensure that formally protected areas remained sustainable parks and reserves, by providing revenues, education in conservation to tourists, community development and jobs, international demand for tourist travel, and self-regulation to ensure that tourism was a net benefit to the nation's forests and wildlife. Although the category was highly fragmented, and spread over different locations, clustering within the country created positive externalities for new entrepreneurs to enter the industry, who could also learn from knowledge spillovers. The perceived commercial viability of many ventures reinforced the case to policymakers and others that forests and wildlife could be worth more when preserved than when used for ranching or farming.

Many of the original ecotourism entrepreneurs were not born in Costa Rica. They were often expatriate Americans who came to the country in search either of biological riches to study or a peaceful society. They brought ecological ideas, whether at the level of academic biology or environmentalist convictions, and together with Costa Rican biologists and environmentalists 
helped to spread these ideas widely. Costa Rica's stability and openness to foreigners allowed these entrepreneurs as well as Costa Rican nationals to start the businesses that created the industry.

At the same time, the creation of the national image of a natural paradise enabled many businesses which were not environmentally sustainable to free-ride on the growing demand for ecotourism. Mass tourism continued to grow, particularly on the beaches of Guanacaste. Greenwashing constituted a serious threat to principled ecotourism businesses. Even the latter faced the dilemma that arose when they expanded the scale of their operations in the 1990s beyond the small number of already-committed ecotourists. By 2000, some of the original ecotourism entrepreneurs were concluding that they could not alter the nature of tourism entirely. They were left with preserving their own forests and wildlife, maintaining a high level of sustainability in their own operations, and hoping to convey their message one tourist at a time.

\section{Acknowledgements}

The authors would like to thank Laura Alfaro, René Castro, Andrew Popp and Megan Epler Wood for insightful comments and suggestions, and the interviewees for reflecting on their experiences in the industry. We would also like to thank the Division of Research and Faculty

Development at the Harvard Business School for funding the research on which this Working Paper is based. A revised version of this Working Paper will be published in Enterprise \& Society. 


\section{Bibliography}

\section{Primary Sources}

Costa Rica Expeditions Archives. "Profits, Prestige, and Repeat Business: A Message from Michael Kaye, President of Costa Rica Expeditions.” May 15, 1994. Costa Rica Expeditions Sales Manual, 1995.

Creating Emerging Markets Project (CEM), Baker Library Historical Collections, Harvard Business School, http://www.hbs.edu/businesshistory/emerging-markets. Interviews by Andrew Spadafora, with Jim Damalas, Jack Ewing, Michael Kaye, and Bary Roberts, 2014.

Interviews by Andrew Spadafora with Tamara Budowski (Mahalakshmi), June 6, 2014; and Efraín Chacón, June 7, 2014.

Royal G. Jackson Papers. Series II.1, Oregon State University Special Collections. Interviews by Royal G. Jackson, with Peter Aspinall, Amos Bien, Tamara Budowski, Carlos Coles, Fernando Esquivel, Diane Ewing, Jack Ewing, Richard Holland, Jim Lewis, Pedro Miranda, Bary Roberts, Mary Ruth, and Louis Wilson, 1992.

Tico Times, 1980-2011.

\section{Books}

Blackford, Mansel. Fragile Paradise: The Impact of Tourism on Maui, 1959-2000. Lawrence, KS: University Press of Kansas, 2001.

Boo, Elizabeth. Ecotourism: The Potentials and Pitfalls. Vol. 2. Washington, DC: World Wildlife Fund, 1990.

Bull, Bartle. Safari: A Chronicle of Adventure. London: Viking, 1988.

Creedman, Theodore S. Historical Dictionary of Costa Rica. 2d ed. Metuchen, NJ: Scarecrow Press, 1991. 
Dauvergne, Peter. Historical Dictionary of Environmentalism. Lanham, MD: Scarecrow Press, 2009.

Davies, R.E.G. Airlines of Latin America since 1919. London: Putnam, 1984.

Davis, Frederick R. The Man Who Saved Sea Turtles: Archie Carr and the Origins of Conservation Biology. Oxford: Oxford University Press, 2007.

Endy, Christopher. Cold War Holidays: American Tourism in France. Chapel Hill, NC: University of North Carolina Press, 2004.

Evans, Sterling. The Green Republic: A Conservation History of Costa Rica. Austin: University of Texas Press, 1999.

Farnham, Timothy. Saving Nature's Legacy: Origins of the Idea of Biological Diversity. New Haven: Yale University Press, 2007.

Fournier, Luis. Desarrollo y perspectiva del movimiento conservacionista costarricense. San José: Editorial de la Universidad de Costa Rica, 1991.

Galizzi, Paolo. The Role of the Environment in Poverty Alleviation. New York: Fordham University Press, 2008.

Hidalgo Capitán, Antonio Luis. Costa Rica en evolución: Política económica, desarrollo y cambio estructural del sistema socioeconómico costarricense, 1980-2002. San José: Universidad de Costa Rica, 2003.

Honey, Martha. Ecotourism and Sustainable Development: Who Owns Paradise? 2d ed. Washington, DC: Island Press, 2008.

Jones, Geoffrey. Profits and Sustainability: A History of Green Entrepreneurship. Oxford: Oxford University Press, forthcoming 2017.

Lindblad, Lars-Eric, with John Fuller. Passport to Anywhere: The Story of Lars-Eric Lindblad New York: Times Books, 1983.

Miller, Kenton. Planning National Parks for Ecodevelopment. Madrid: Fundación para la Ecologia y para la Protección del Medio Ambiente, 1978.

Moss, Stephen. A Bird in the Bush: A Social History of Bird-Watching. London: Aurum Press, 2004.

Orsi, Richard J. Sunset Limited: The Southern Pacific Railroad and the Development of the American West, 1850-1930. Berkeley: University of California Press, 2005. 
Porras, Ina, David Barton, Adriana Chacón-Cascante, and Miriam Miranda. Learning from 20 Years of Payments for Ecosystem Services in Costa Rica. London: International Institute for Environment and Development, 2013.

Quesada Castro, Renato, and Estrella Guier Serrano. Ambiente y turismo sostenible. San José: EUNED, 2014.

Rankin, Monica. The History of Costa Rica. Santa Barbara, CA: Greenwood, 2012.

Rawcliffe, Peter. Environmental Pressure Groups in Transition. Manchester: Manchester University Press, 1998.

Roberts, W. Dayton. One Step Ahead: the Innovative Strachans and the Birth of Latin American Mission. Miami, FL: Latin American Mission, 1996.

Rodríguez Chaverri, Camilo. Efraín Chacón: El padre de San Gerardo. San José: Maya \& PZ Editorial, 2008.

- Mujeres pioneras del turismo en Costa Rica. San José: Maya \& PZ Editorial, 2006.

Scranton, Philip and Janet P. Davidson, eds. The Business of Tourism: Place, Faith and History. Philadelphia: University of Pennsylvania Press, 2007.

Steinberg, Paul F. Environmental Leadership in Developing Countries: Transnational Relations and Biodiversity Policy in Costa Rica and Bolivia. Cambridge: MIT Press, 2001.

Strong, Maurice. Where on Earth are We Going? New York: Texere, 2000.

Tissot, Laurent. Naissance d'une industrie touristique: les Anglais et la Suisse au X1Xe siècle. Lausanne: Editions Payot, 2000.

Van Gulik, Ilse. Green or Gold? Sustainable Tourism in Costa Rica and the Actors Involved. Nijmegen: Catholic University of Nijmegen Press, 1999.

Wallace, David Rains. The Quetzal and the Macaw: The Story of Costa Rica's National Parks. San Francisco: Sierra Club, 1992.

Weaver, David. Ecotourism in the Less Developed World. New York: CABI, 1998.

Weinberg, War on the Land: Ecology and Politics in Central America. London: Zed Books, 1991.

Wilson, Bruce M. Costa Rica: Politics, Economics, and Democracy. Boulder: Lynne Rienner, 1998. 


\section{Articles and Chapters}

Bien, Amos. "Environmental Certification for Tourism in Central America: CST and Other Programs.” In Ecotourism \& Certification: Setting Standards in Practice, edited by Martha Honey, 133-159. Washington, D.C.: Island Press, 2002.

Bangs, Richard. "Meet the Godfather of Ecotourism.” (1999). Accessed at http://www.costaricaexpeditions.com/Articles/article.php?id=43, May 2014.

Blake, Beatrice, Anne Becher, and Jane Segleau Earle. "Evaluating Ecotourism Lodgings in the New Key to Costa Rica.” Yale School of Forestry \& Environmental Studies Bulletin 99 (1996): 141-152.

Budowski, Gerardo. “Tourism and Environmental Conservation: Conflict, Coexistence, or Symbiosis?” Environmental Conservation 3:1 (1976): 27-31.

Budowski, Tamara. “Ecotourism Costa Rican Style.” In Toward a Green Central America: Integrating Conservation and Development, edited by Valerie Barzetti and Yanina Rovinski, 4862. West Hartford, CT: Kumarian Press, 1992.

Butler, R.W. "The Concept of a Tourist Area Cycle of Evolution: Implications for Management of Resources.” Canadian Geographer 24:1 (1980): 5-12.

Churchill, David. "American Expatriates and the Building of Alternative Social Space in Toronto, 1965-1977.” Urban History Review 39:1 (2010): 31-44.

Cirer-Costa, Joan Carles. "Majorca’s Tourism Cluster: The Creation of an Industrial District, 1919-36.” Business History 56:8 (2014): 1243-1261.

Coldwell, Norma. "The History of Braniff in Peru.” Masters Thesis, North Texas State University. Denton, TX: 1970.

Deshazo, J.R. "Linking the Growth of Tourism with the Conservation of Protected Areas." In Environment for Growth in Central America, edited by Theodore Panayotou, 231-256. Cambridge: Harvard University Press, 2001.

Furlough, Ellen. “Club Méditerranée, 1950-2002.” In Europe at the Seaside, edited by Luciano Segreto, Carles Manera, and Manfred Pohl, 174-195. New York: Berghahn, 2009.

Gámez, Rodrigo and Vilma Obando. “La Biodiversidad.” In Costa Rica en el siglo XX, Volume 2, edited by Eugenio Rodríguez Vega, 139-191. San José: EUNED, 2004.

Inman, Crist. "Tourism in Costa Rica: The Challenge of Competitiveness.” CLACDS Working Paper, March 2002. 
Jobs, Richard Ivan. "Youth Movements: Travel, Protest, and Europe in 1968.” American Historical Review 114:2 (2009): 376-404.

Kaye, Michael. “Responsible Travel to Natural Areas.” Condé Nast Traveler. November, 2002.

Laarman, Jan and Richard Perdue. "Science Tourism in Costa Rica.” Annals of Tourism Research 16 (1989): 205-215.

Laarman, Jan and Richard Perdue. "A Survey of Return Visits to Costa Rica by OTS Participants and Associates.” Working Paper. Research Triangle Park, NC: Southeastern Center for Forestry Economics Research, 1987.

Langholz, Jeff. "Conservation Cowboys: Privately-Owned Parks and the Protection of Biodiversity in Costa Rica.” Ph.D. Diss., Cornell University, 1999.

Marín Hernández, Juan José and Ronny Viales Hurtado, “Turismo y ambiente en la 'Perla’ del Pacifico, 1946-1980.” Diálogos: Revista Electrónica de Historia (Oct. 2012): 151-205.

Miranda, Sergio. “Estación Biológica Marenco y Marenco Beach \& Rainforest Lodge.” In Realidades y Visiones en la Gestión ambiental y ecoturística: Memoria del primer simposio internacional, Red Interamericana de Formación-Gestión Ambiental y Ecoturismo, 57-60. San José: Universidad de Costa Rica, 2001.

Observatorio del Turismo del Pacifico Norte, "El origen de la actividad turística en Costa Rica: de la junta nacional de turismo al ICT.” Revista Umbral, 22 (2008): 42-52.

Quek, Mary. "Globalising the Hotel Industry, 1946-1968: A Multinational Case Study of the Intercontinental Hotel Corporation.” Business History 54:2 (2012): 201-226.

Rome, Adam. “'Give Earth a Chance’: The Environmental Movement and the Sixties.” Journal of American History 90:2 (2003): 525-554.

Rovinski, Yanina. "Private Reserves, Parks, and Ecotourism in Costa Rica." In Nature Tourism: Managing for the Environment, edited by Tensie Whelan, 39-57. Washington, DC: Island Press, 1991.

Suri, Jeremi. “The Rise and Fall of an International Counterculture, 1960-1975.” American Historical Review 144:1 (2009): 45-68.

Walton, John. "Seaside Tourism in Europe: Business, Urban, and Comparative History." Business History 53:6 (2011): 900-916.

Weaver, David and Laura Lawton. "Twenty Years On: The State of Contemporary Ecotourism Research.” Tourism Management 28 (2007): 1168-1179. 
Young, A.M. "Eco-Enterprises: Eco-Tourism and Farming of Exotics in the Tropics.” Ambio 15:6 (1986): 361-363.

\section{Endnotes}

${ }^{1}$ Weaver, Ecotourism, 84 (for 1970) and Hidalgo Capitán, Costa Rica en evolucion, 255 (for 2000).

${ }^{2}$ Honey, Ecotourism, 6-10, 15-16.

${ }^{3}$ Gámez and Obando, “La Biodiversidad,” 179.

${ }^{4}$ Deshazo, “Linking the Growth in Tourism,” 253. The survey was conducted in 1997.

${ }^{5}$ Inman, “Tourism in Costa Rica,” 110.

${ }^{6}$ Honey, Ecotourism, 160.

7 “Top Five Destinations for Ecotourism,” http://www.independenttraveler.com/traveltips/none/top-five-destinations-for-ecotourism, accessed June 11, 2016.

8 “Top 10 Ecotourism Destinations,” (April 18, 2013), http://blog.shermanstravel.com/2013/top10-ecotourism-destinations, accessed June 5, 2016.

${ }^{9}$ Scranton and Davidson, Business, vii-viii.

10 Tissot, Naissance.

${ }^{11}$ Orsi, Sunset.

12 Endy, Cold War Holidays; Quek, “Globalizing.”

${ }^{13}$ Quek, “Globalizing,” 205; Coldwell, “History of Braniff.”

${ }^{14}$ Furlough, “Club Méditerranée”; Blackford, Fragile Paradise.

${ }^{15}$ Walton, “Seaside Tourism”; Cirer-Costa, “Majorca’s Tourism Cluster.”

${ }^{16}$ Weaver and Lawton, “Twenty Years On.” This assessment remains true nearly a decade later. 
17 Bull, Safari; Moss, Bird in the Bush; Lindblad and Fuller, Passport to Anywhere; Jones, Profits.

${ }^{18}$ See above all Fournier, Desarrollo; Wallace, Quetzal; Evans, Green Republic.

${ }^{19}$ Honey, Ecotourism, 160; Steinberg, Environmental Leadership, 150.

${ }^{20}$ Weaver, Ecotourism, 81.

${ }^{21}$ Gámez and Obando, “La Biodiversidad,” 151. The rate dropped to an average of 43,000 hectares annually in the 1980s, to 13,000 hectares in 1993, and to 3000 hectares in 2000.

22 Evans, Green Republic, 40.

${ }^{23}$ Marín Hernández and Viales Hurtado, “Turismo y ambiente,” 185; Honey, Ecotourism, 162.

${ }^{24}$ Creedman, Historical Dictionary of Costa Rica, 139.

${ }^{25}$ Rankin, History of Costa Rica, 117, 153.

${ }^{26}$ Hazel Barahona, “Aeropuerto de Liberia aún no despega,” La Nación, May 27, 1996.

27 Davies, Airlines of Latin America, 94, 98-102; International Directory of Company Histories, Vol. 38, “Grupo TACA,” 218-220.

${ }^{28}$ Observatorio del Turismo, “El origen.”

${ }^{29}$ Evans, Green Republic, 56-57.

${ }^{30}$ Observatorio del Turismo, “El origen,” 51.

${ }^{31}$ See, for instance, Jean Hopfensperger, “Wilderness Adventures Spice Up Local Travel,” Tico Times, October 10, 1980, cited in Honey, Ecotourism, 15.

${ }^{32}$ Honey, Ecotourism, 162-163.

33 Interviews with Louis Wilson, May 4, 1992, and Mary Ruth, August 21, 1992.

34 Jerry Ruhlow, “Tourism Groups to Battle Law,” Tico Times, August 15, 1986, pp. 1, 8. 
35 Jerry Ruhlow, "Tourism to Get Private Push,” Tico Times, August 1, 1986, pp. 1, 3; Jerry

Ruhlow, “Tourism Committee Resigns,” Tico Times, August 29, 1986, pp. 1, 4.

${ }^{36}$ Honey, Ecotourism, 164-167. For impressions of the ICT, see below.

${ }^{37}$ Wilson, Costa Rica, 11-14, 18-23.

${ }^{38}$ Wilson, Costa Rica, Chapter 4; Rankin, History of Costa Rica, Chapters 8-9.

${ }^{39}$ For a relatively favorable account of these reforms, see Hidalgo Capitán, Costa Rica en evolución, Chapters 2 and 3; for a negative view, see Weinberg, War on the Land, Chapter 12.

${ }^{40}$ Weaver, Ecotourism, 84; Rovinski, “Private Reserves,” 56.

${ }^{41}$ Fournier, Desarrollo, 22-51; Evans, Green Republic, 54-57.

${ }^{42}$ Fournier, Desarrollo, 40-43, Steinberg, Environmental Leadership, 52-54.

${ }^{43}$ Evans, Green Republic, 23-25; Steinberg, Environmental Leadership, 54.

${ }^{44}$ Davis, Man Who Saved Sea Turtles, esp. 111-117; Wallace, Quetzal, 41-42.

${ }^{45}$ Evans, Green Republic, 26; Fournier, Desarrollo, 58-59.

${ }^{46}$ Fournier, Desarrollo, 58.

${ }^{47}$ Farnham, Saving Nature’s Legacy, 214.

${ }^{48}$ Ibid., Chapter 1.

${ }^{49}$ Rawcliffe, Environmental Pressure Groups, 28; Dauvergne, Historical Dictionary, liii, 148.

${ }^{50}$ Moss, Bird in the Bush.

${ }^{51}$ Interview with Efraín Chacón, June 7, 2014; Interview with Carlos Coles, August 26, 1992; Interview with Peter Aspinall, October 13, 1992.

${ }^{52}$ Wallace, Quetzal, 6-10. 
${ }^{53}$ For Monteverde, long the most popular Costa Rican ecotourism destination, see especially Aylward et al., "Sustainable Ecotourism in Costa Rica,” 323-328; Honey, Ecotourism, 184-189; van Gulik, Green or Gold, 89-93.

${ }^{54}$ Boo, Ecotourism, 38.

${ }^{55}$ Wallace, Quetzal, 108-111; Honey, Ecotourism, 193.

${ }^{56}$ Laarman and Perdue, “Science Tourism in Costa Rica,” 206, 211-212.

${ }^{57}$ Blake and Becher, New Key, $6^{\text {th }}$ ed., 126, observed that a day at La Selva, including access to the trails, three meals, and rustic accommodations, cost \$60 in 1986.

${ }^{58}$ Honey, Ecotourism, 194.

${ }^{59}$ Gerardo Budowski, “Tourism and Environmental Conservation,” 30; Laarman and Perdue, "Survey of Return Visits to OTS," 17.

${ }^{60}$ Evans, Green Republic, 24; Miller, Planning National Parks for Ecodevelopment; Gerardo Budowski, "Tourism and Environmental Conservation.”

${ }^{61}$ Evans, Green Republic, 73-75; Wallace, Quetzal, 14-15.

${ }^{62}$ Ibid., 64-73.

63 See above all, Evans, Green Republic, Chapters 4-8; and Wallace, Quetzal, 11-106 and Chapter 17; Fournier, Desarrollo, 62-75.

${ }^{64}$ Evans, Green Republic, 229.

${ }^{65}$ René Castro, Personal Communication.

${ }^{66}$ Evans, Green Republic, 171 and Wallace, Quetzal, 118, 190-191, 193.

${ }^{67}$ Honey, Ecotourism, 170-172.

${ }^{68}$ Michael Kaye, quoted in Wallace, Quetzal, 121.

${ }^{69}$ Suri, “Rise and Fall.” Quotation on p. 51. 
70 Jobs, "Youth Movements."

${ }^{71}$ Churchill, “American Expatriates.”

72 Rome, “Give Earth a Chance.””

${ }^{73}$ Staley, "Remembering Archie Fields"; for the Jungle Tours, see frequent advertisements in The Tico Times, 1980s.

74 Adams, “Discovery of Costa Rica”; http://www.calypsocruises.com/About_us/ CalypsoCruises/History/Articles/

${ }^{75}$ Interview with Louis Wilson, May 4, 1992.

${ }^{76}$ Ibid.

${ }^{77}$ Interview with Mary Ruth, August 21, 1992.

${ }^{78}$ Interview with Louis Wilson, May 4, 1992.

${ }^{79}$ Interview with Mary Ruth, August 21, 1992.

${ }^{80}$ Interview with Carlos Coles, August 26, 1992.

${ }^{81}$ Interview with Michael Kaye, June 5, 2014, Creating Emerging Markets Project (hereafter CEM), Baker Library Historical Collections, Harvard Business School.

${ }^{82}$ Interview with Jim Lewis, November 2, 1992.

${ }^{83}$ Interview with Jim Lewis, November 2, 1992; Interview with Michael Kaye, June 5, 2014, CEM.

${ }^{84}$ Interview with Michael Kaye, June 5, 2014, CEM.

${ }^{85}$ Interview with Fernando Esquivel, July 30, 1992.

${ }^{86}$ Interview with Jim Lewis, November 2, 1992; Quesada Castro and Guier Serrano, Ambiente y turismo sostenible, 346.

87 “Vast Tourism Resources Untapped in Costa Rica,” Wall Street Journal, October 20, 1988. 
${ }^{88}$ Interview with Michael Kaye, June 5, 2014, CEM; Jerry Ruhlow, “Tour Operators: Don’t Overlook Our Fishing!”, Tico Times, October 3, 1986, p. 17.

${ }^{89}$ Interview with Michael Kaye, June 5, 2014, CEM.

${ }^{90}$ Interview with Jim Lewis, November 2, 1992.

${ }^{91}$ Rovinski, "Private Reserves,” 46-47.

${ }^{92}$ Michael Kaye, “Profits, Prestige, and Repeat Business,” May 15, 1994.

${ }^{93}$ Interview with Michael Kaye, June 5, 2014, CEM.

${ }^{94}$ Interview with Richard Holland, August 28, 1992.

${ }^{95}$ Interview with Michael Kaye, June 5, 2014, CEM.

${ }^{96}$ Cited in Honey, Ecotourism, 15; and Kaye, "Responsible Travel to Natural Areas.”

${ }^{97}$ Interview with Michael Kaye, June 5, 2014, CEM.

${ }^{98}$ Michael Kaye, "Profits, Prestige, and Repeat Business"; Kaye quoted in Bangs, "Meet the Godfather of Ecotourism.”

${ }^{99}$ Interview with Bary Roberts, June 9, 2014, CEM; on the Roberts-Strachan family, see W.D. Roberts, One Step Ahead.

${ }^{100}$ Interview with Bary Roberts, June 9, 2014, CEM. On Strong and the Stockholm meeting, see Jones, Profits and Strong, Where, chapter 6.

${ }^{101}$ Michelle Sheaff, "Summit Organizer Charged with Violating National Laws,” Tico Times, June 5, 1992, p.1.

${ }^{102}$ Interview with Bary Roberts, September 9, 1992.

${ }^{103}$ Ibid.

${ }^{104}$ Ibid.

${ }^{105}$ Interview with Bary Roberts, June 9, 2014, CEM. 
${ }^{106}$ Interview with Bary Roberts, June 9, 2014, CEM; Young, “Eco-Enterprises,” 362.

${ }^{107}$ Interview with Bary Roberts, September 9, 1992.

${ }^{108}$ Interview with Bary Roberts, September 9, 1992.

109 Ibid.; Interview with Tamara Budowski, June 6, 2014.

110 Interview with Tamara Budowski, June 6, 2014; “Ana Margarita Forero,” in Rodriguez Chaverri, Mujeres pioneras, 140.

${ }^{111}$ Interview with Tamara Budowski, June 6, 2014.

112 Interview with Tamara Budowski, September 21, 1992; Interview with Tamara Budowski, June 6, 2014.

113 Interview with Tamara Budowski, June 6, 2014.

114 Interview with Tamara Budowski, June 6, 2014; “Ana Margarita Forero,” in Rodriguez Chaverri, Mujeres pioneras, 141-146.

115 Interview with Tamara Budowski, June 6, 2014.

116 Interview with Tamara Budowski, September 21, 1992; “Tamara Budowski,” in Rodriguez Chaverri, Mujeres pioneras, 151-152.

117 “Ana Margarita Forero,” in Rodriguez Chaverri, Mujeres pioneras, 147-148. Quotation cited in Evans, Green Republic, 222.

${ }^{118}$ Interview with Tamara Budowski, June 6, 2014.

119 “Tamara Budowski,” in Rodriguez Chaverri, Mujeres pioneras, 154.

${ }^{120}$ Interview with Tamara Budowski, June 6, 2014. Galizzi, Role of the Environment, 113-116.

${ }^{121}$ Interview with Tamara Budowski, September 21, 1992.

122 Budowski, “Ecotourism Costa Rican Style,” 52.

123 Ibid., 52. 
${ }^{124}$ Interview with Tamara Budowski, June 6, 2014.

125 Tamara Budowski, “Ecotourism Costa Rican Style,” 50.

${ }^{126}$ For a thoughtful study of the private reserve movement in Costa Rica in the 1990s, see Langholz, “Conservation Cowboys.”

127 This account of Rara Avis relies on the following source unless otherwise noted: Interview with Amos Bien, October 2, 1992.

${ }^{128}$ Honey, Ecotourism, 196; Interview with Amos Bien, October 2, 1992.

${ }^{129}$ Interview with Amos Bien, October 2, 1992.

${ }^{130}$ Evans, Green Republic, 222.

${ }^{131}$ Interview with Amos Bien, October 2, 1992.

132 On Perry, see Honey, Ecotourism and Sustainable Development, 198, 200.

133 Interview with Pedro Miranda, October 14, 1992; for the correct date of 1974, see Sergio Miranda, “Estación Biológica Marenco y Marenco Beach \& Rainforest Lodge,” 58.

${ }^{134}$ Sergio Miranda, “Estación,” 58.

135 Sergio Miranda, “Estación,” 59.

136 Interview with Pedro Miranda, October 14, 1992.

137 Ibid.; Sergio Miranda, “Estación,” 58.

${ }^{138}$ Interview with Pedro Miranda, October 14, 1992; Sergio Miranda, “Estación,” 59.

${ }^{139}$ Interview with Efraín Chacón, June 7, 2014.

${ }^{140}$ Rodríguez Chaverri, Efraín Chacón, 25-29.

${ }^{141}$ Interview with Efraín Chacón, June 7, 2014.

142 Rodríguez Chaverri, Efraín Chacón, 29.

${ }^{143}$ Interview with Efraín Chacón, June 7, 2014. 
${ }^{144}$ Interview with Jack Ewing, June 3, 2014, CEM.

${ }^{145}$ Interview with Jack Ewing, November 4, 1992.

146 Ibid.

${ }^{147}$ Interview with Jack Ewing, June 3, 2014, CEM.

${ }^{148}$ Interview with Jack Ewing, November 4, 1992.

${ }^{149}$ Interview with Diane Ewing, November 5, 1992.

${ }^{150}$ Interview with Jack Ewing, June 3, 2014, CEM.

${ }^{151}$ Interview with Diane Ewing, November 5, 1992.

152 Interview with Jack Ewing, November 4, 1992.

153 Interview with Jack Ewing, June 3, 2014, CEM.

154 Interview with Jack Ewing, November 4, 1992.

155 Honey, Ecotourism, 162.

${ }^{156}$ Inman, “Tourism in Costa Rica,” 18.

157 Gámez and Obando, “La Biodiversidad,” 177.

158 Evans, Green Republic, 7.

159 Porras et al., Learning, 8-9.

160 Gámez and Obando, “La Biodiversidad,” 177; Honey, Ecotourism, 164-167.

161 Butler, “Tourist Area Cycle.”

162 Interview with Richard Holland, August 28, 1992.

163 Blake, Becher, and Earle, "Evaluating Ecotourism Lodgings in The New Key to Costa Rica," $141-143$.

164 Bien, “Environmental Certification,” 138-139. 
165 Bien, “Environmental Certification,” 147-149; Interview with Bary Roberts, June 9, 2014, CEM.

${ }^{166}$ Interview with Bary Roberts, June 9, 2014, CEM.

${ }^{167}$ Bien, “Environmental Certification,” 150; Interview with Jim Damalas, June 4, 2014, CEM.

168 Jones, Profits.

${ }^{169}$ On this hotel and competitors like Hotel Punta Islita, see Honey, Ecotourism, 167-169, 175-

177.

${ }^{170}$ Interview with Jim Damalas, June 4, 2014, CEM.

${ }^{171}$ Interview with Jim Damalas, June 4, 2014, CEM.

172 Interview with Mary Ruth, August 21, 1992.

${ }^{173}$ Interview with Tamara Budowski, June 6, 2014.

${ }^{174}$ Interview with Michael Kaye, June 5, 2014, CEM. 